several authors ${ }^{29-32}$. Nevertheless, most studies dealing with long and well dated sequences conclude either that a 30-50 kyr geomagnetic pulse $\mathrm{e}^{5,6}$ exists, or that there is no dominant period. But a correlation has been found ${ }^{11}$ between the 41 -kyr obliquity cycle and palaeointensity variations; this was based on the analysis of a very detailed and precisely dated sequence ${ }^{11}$ from Ocean Drilling Project Site 983 . We performed a spectral analysis of Sint-800 using the Blackman-Tukey technique with the AnalySeries software ${ }^{33}$. In order to investigate the stability of the results, we first analysed the entire signal and then restrained the analysis to the $0-400 \mathrm{kyr}$ interval which incorporates more records. The spectral contents of these two intervals are significantly different. The same conclusion is reached by comparing every 400 -kyr-long interval in increments of $100 \mathrm{kyr}$ with the $0-800 \mathrm{kyr}$ period (Fig. 3 ). These results point out the absence of any dominant stable periodicity. For comparison, the same analysis performed with the $\delta^{18} \mathrm{O}$ curve $\mathrm{e}^{20}$ shows perfect reproducibility of the orbital peaks $(23,41$ and $100 \mathrm{kyr})$ over each interval. (An additional indication supporting these conclusions is that the artificial 41-kyr signal created after band-pass-filtering Sint800 has a different phase and a much smaller amplitude than the signal obtained by the same procedure for site 983.) Similar observations and conclusions are reached without incorporating the site 983 record in the database. Orbital modulation of the geomagnetic field should primarily affect the dipole field, and therefore should be present in Sint- 800 which incorporates at least 20 data points per $41 \mathrm{kyr}$. However, for periods shorter than $40 \mathrm{kyr}$ it is possible that uncertainties due to dating and/or smoothing inherent to the stacking process induced loss of spectral power (Fig. 3b). This may explain the pattern observed in the coherence functions between Sint-800 and data from site 983 (Fig. 3c) for these short periods.

Our composite Sint- 800 curve shows that the Earth's dipole field over the past $800 \mathrm{kyr}$ was dominated by changes of very large (and various) amplitude but does not indicate the presence of any dominant periodicity. The mean field value remained more or less constant. Geomagnetic excursions are observed when the dipole moment decreases to a critical value of about $4 \times 10^{22} \mathrm{~A} \mathrm{~m}^{2}$, and such excursions must thus be seen as direct consequences of the overall 'secular' variation of the dipole field.

Received 11 January; accepted 29 March 1999.

1. Guyodo, Y. \& Valet, J.-P. Relative variations in geomagnetic intensity from sedimentary records: the past 200,000 years. Earth Planet. Sci. Lett. 143, 23-36 (1996).

2. Frank, M. et al. A $200 \mathrm{kyr}$ record of cosmogenic radionuclide production rate and geomagnetic field intensity from ${ }^{10} \mathrm{Be}$ in globally stacked deep-sea sediments. Earth Planet. Sci. Lett. 149, 121-129 (1997).

Tric, E. et al. Paleointensity of the geomagnetic field for the last 80,000 years. J. Geophys. Res. 97, 9337 9351 (1992).

4. Meynadier, L., Valet, J.-P., Weeks, R., Shackleton, N. \& Hagee, V. L. Relative geomagnetic intensity of the field during the last $140 \mathrm{ka}$. Earth Planet. Sci. Lett. 114, 39-57 (1992).

5. Tauxe, L. \& Wu, G. Normalised remanence in sediments from western equatorial Pacific: relative paleointensity of the geomagnetic field. J. Geophys. Res. 95, 12337-12350 (1990).

6. Tauxe, L. \& Shackleton, N. J. Relative paleointensity records from the Ontong-Java Plateau. Geophys. J. Int. 117, 769-782 (1994).

7. Yamazaki, T. \& Ioka, N. Long-term secular variation of the geomagnetic field during the last $200 \mathrm{k} . \mathrm{y}$. recorded in sediment cores from the western equatorial Pacific. Earth. Planet. Sci. Lett. 128, 527-544 (1994).

8. Lehman, B. et al. Relative changes of the geomagnetic field intensity during the last 280 kyear from piston cores in the Acores area. Phys. Earth Planet. Inter. 93, 269-284 (1996).

9. Schneider, D. A. Late Pleistocene and Holocene geomagnetic intensity variations recorded in Sulu Sea sediments. Eos (suppl.) 75, S119 (1994).

10. Stoner, J. S., Channell, J. E. T. \& Hillaire-Marcel, C. A 200 ka chronostratigraphy for the Labrador Sea: Indirect correlation of the sediment record to SPECMAP. Earth. Planet. Sci. Lett. 159, 165-181 (1998).

11. Channell, J. E. T., Hodell, D. A., McManus, J. \& Lehman, B. Orbital modulation of the Earth's magnetic field intensity. Nature 394, 464-468 (1998).

12. Valet, J.-P., Meynadier, L., Bassinot, F. \& Garnier, F. Relative paleointensity across the last geomagnetic reversal from sediments of the Atlantic, Indian and Pacific Oceans. Geophys. Res. Lett. 21, 485-488 (1994).

13. Schneider, D. A. \& Mello, G. A. A high-resolution marine sedimentary record of geomagnetic intensity during the Brunhes Chron. Earth Planet. Sci. Lett. 144, 297-314 (1996).

14. Yamazaki, T., Ioka, N. \& Eguchi, N. Relative paleointensity of the geomagnetic field during the Brunhes Chron. Earth Planet. Sci. Lett. 136, 525-540 (1995).

15. Meynadier, L., Valet, J.-P., Bassinot, F., Shackleton, N. \& Guyodo, Y. Asymmetrical saw-tooth pattern of the geomagnetic field intensity from equatorial sediments in the Pacific and Indian Oceans. Earth Planet. Sci. Lett. 126, 109-127 (1994).

16. Meynadier, L. \& Valet, J.-P. Relative geomagnetic intensity during the last $4 \mathrm{~m} . \mathrm{y}$. from the equatorial Pacific. Proc. ODP Sci. Res. 138, 779-795 (1995).
17. Meynadier, L., Valet, J.-P., Guyodo, Y. \& Richter, C. Saw-toothed variations of relative paleointensity and cumulative viscous remanence: Testing the records and the model. J. Geophys. Res. 103, 70957105 (1998).

18. Guyodo, Y., Richter, C. \& Valet, J.-P. Paleointensity record from the Pleistocene sediments (1.4-0 Ma) off the California Margin. J. Geophys. .Res. (in the press).

19. Kent, D. V. \& Opdyke, N. D. Paleomagnetic field intensity recorded in a Brunhes epoch deep-sea sediment core. Nature 266, 156-159 (1977).

20. Bassinot, F. C. et al. The astronomical theory of climate and the age of the Brunhes-Matuyama magnetic reversal. Earth Planet. Sci. Lett. 126, 91-108 (1994).

21. Martinson, D. G. et al. Age dating and the orbital theory of the Ice Ages: development of a highresolution 0 to 300,000-year chronostratigraphy. Quat. Res. 27, 1-29 (1987).

22. Merill, R. T., Mc Elhinny, M. W. \& McFadden, P. L. (eds) The Magnetic Field of the Earth (Int. Geophysics Ser., Academic, London, 1998).

23. Valet, J.-P. \& Meynadier, L. Geomagnetic field intensity and reversals during the past four million years. Nature 366, 91-95 (1993)

24. Merill, R. T. \& McFadden, P. L. Geomagnetic stability: Reversal events and excursions. Earth Planet. Sci. Lett. 121, 57-69 (1994).

25. Langereis, C. G., Dekkers, M. J., de Lange, G. J., Paterne, M. \& van Santvoort, P. J. M. Magnetostratigraphy and astronomical calibration of the last $1.1 \mathrm{Myr}$ from an eastern Mediterranean piston core and dating of short events in the Brunhes. Geophys. J. Int. 129, 75-94 (1997).

26. Quidelleur, X., Gillot, P. Y. \& Carlut, J. Link between excursions and paleointensity inferred from abnormal field directions recorded at La Palma around $600 \mathrm{ka}$. (suppl.) 78, F181 (1997).

27. Champion, D. E., Lanphere, M. A. \& Kuntz, M. A. Evidence for a new geomagnetic reversal from lava flows in Idaho: Discussion of short polarity reversals in the Brunhes and late Matuyama polarity chrons. J. Geophys. Res. 93, 11667-11680 (1988).

28. Worm, H.-U. A link between geomagnetic reversals, events and glaciations. Earth Planet. Sci. Lett. 177, 55-67 (1997)

29. Malkus, W. V. R. Precession of the earth as the cause of geomagnetism. Science 160, 259-264 (1968). 30. Wollin, G., Ericson, D. B. \& Ryan, W. B. F. Magnetism of the earth and climatic changes. Earth Planet. Sci. Lett. 12, 171-183 (1971)

31. Creer, K. M., Thouveny, N. \& Blunk, I. Climatic and geomagnetic influences on the Lac du Bouchet paleomagnetic record through the last 110,000 years. Phys. Earth Planet. Inter. 64, 314-341 (1990).

32. Vanyo, J. P. A geodynamo powered by luni-solar precession. Geophys. Astrophys. Fluid Dyn. 59, 209234 (1991)

33. Paillard, D., Labeyrie, L. \& Yiou, P. Macintosh program performs time-series analysis. Eos 77, 379 (1996).

Supplementary information is available on Nature's World-Wide Web site (http://www.nature.com) or as paper copy from the London editorial office of Nature.

Acknowledgements. We thank J. E. T. Channell, C. Laj, L. Meynadier, D. A. Schneider, J. S. Stoner, L. Tauxe and T. Yamazaki for supplying data, and F. C. Bennett for comments. This work was supported by the CNRS-INSU program Intérieur de la Terre. At this University of Florida, Y.G. was supported by a grant awarded to J. E. T. Channell.

Correspondence and requests for material should be addressed to Y.G. (e-mail: guyodo@ufl.edu). Data from sites 983 and 984 are available from J.E.T. Channell at the University of Florida (e-mail: jetc@nerdc.ufl.edu).

\section{Nature of the Earth's earliest crust from hafnium isotopes in single detrital zircons}

\author{
Yuri Amelin ${ }^{\star}$, Der-Chuen Lee $\dagger$, Alex N. Halliday $\ddagger$ \\ \& Robert T. Pidgeon $\$$
}

* Department of Earth Sciences, Royal Ontario Museum, Toronto,

Ontario M5S 2C6, Canada

$\dagger$ Department of Geological Sciences, University of Michigan, Ann Arbor, Michigan 48109, USA

¥Department of Earth Sciences, ETH, Zurich, CH-8092, Switzerland

$\$$ School of Applied Geology, Curtin University of Technology, Bentley, WA 6102, Australia

Continental crust forms from, and thus chemically depletes, the Earth's mantle. Evidence that the Earth's mantle was already chemically depleted by melting before the formation of today's oldest surviving crust has been presented in the form of Sm-Nd isotope studies of 3.8-4.0 billion years old rocks from Greenland $^{1-5}$ and Canada $\mathrm{C}^{5-7}$. But this interpretation has been questioned because of the possibility that subsequent perturbations may have re-equilibrated the neodymium-isotope compositions of these rocks $^{8}$. Independent and more robust evidence for the origin of the earliest crust and depletion of the Archaean mantle can potentially be provided by hafnium-isotope compositions of zircon, a mineral whose age can be precisely determined by $\mathrm{U}-\mathrm{Pb}$ dating, and which can survive metamorphisms ${ }^{4}$. But the amounts of hafnium in single zircon grains are too small for the isotopic composition to be precisely analysed by conventional methods. 
Here we report hafnium-isotope data, obtained using the new technique of multiple-collector plasma-source mass spectrometry ${ }^{9}$, for 37 individual grains of the oldest known terrestrial zircons (from the Narryer Gneiss Complex, Australia, with $\mathrm{U}-\mathrm{Pb}$ ages of up to 4.14 Gyr (refs 10-13)). We find that none of the grains has a depleted mantle signature, but that many were derived from a source with a hafnium-isotope composition similar to that of chondritic meteorites. Furthermore, more than half of the analysed grains seem to have formed by remelting of significantly older crust, indicating that crustal preservation and subsequent reworking might have been important processes from earliest times.

Zircon is well suited for Hf-isotope studies of ancient rocks. It has high $\mathrm{Hf}$ concentrations and low Lu/Hf ratios, so that correction for in situ radiogenic growth is negligible. It can be precisely dated by $\mathrm{U}-\mathrm{Pb}$ techniques and these data can confirm whether the zircon remained a closed system. Zircon is extremely resistant and can survive erosion or metamorphism that might modify or destroy its host rock. Therefore, zircon has been successfully used in many LuHf isotope studies ${ }^{4,14,15}$. But at least $1-2 \mu \mathrm{g}$ of $\mathrm{Hf}$ (and therefore $100-200 \mu \mathrm{g}$ of zircon) is normally required for precise analysis. This precludes studies of detrital zircons where grains come from various sources and must be analysed individually. The recently developed multiple-collector inductively coupled plasma-source mass spectrometer (MC-ICPMS) allows precise isotopic analysis of $30-50 \mathrm{ng} \mathrm{Hf}$ (refs 16,17), the amount of Hf present in a single $3-5-\mu$ gircon grain. This level of analytical sensitivity allows us, we believe for the first time, to analyse Hf grain by grain from a detrital zircon population rather than in bulk $^{18}$, and to elucidate the earliest history of the continental crust.

Newly formed crust inherits the Hf-isotope composition of its mantle source, and this can be relatively unradiogenic $\left(\epsilon_{\mathrm{Hf}}(T)<0\right)$ or radiogenic $\left(\epsilon_{\mathrm{Hf}}(T)>0\right)$ Hf depending on whether the mantle from which it was derived was respectively enriched or depleted $\left(\epsilon_{\mathrm{Hf}}(T)\right.$ is defined in Fig. 2 legend). Zircons crystallized from felsic magmas formed by melting of continental crust have initial Hfisotope compositions which indicate the Hf-isotope composition of a particular sample of the continental crust. For example, if granites were formed by melting of juvenile crust that had recently formed from depleted mantle, as in many modern arcs, the zircons would have radiogenic initial Hf-isotope compositions $\left(\epsilon_{\mathrm{Hf}}(T)>0\right)$ close to that of the mantle source. However, if granite formation occurred by reworking of old continental crust, the newly crystallized zircon

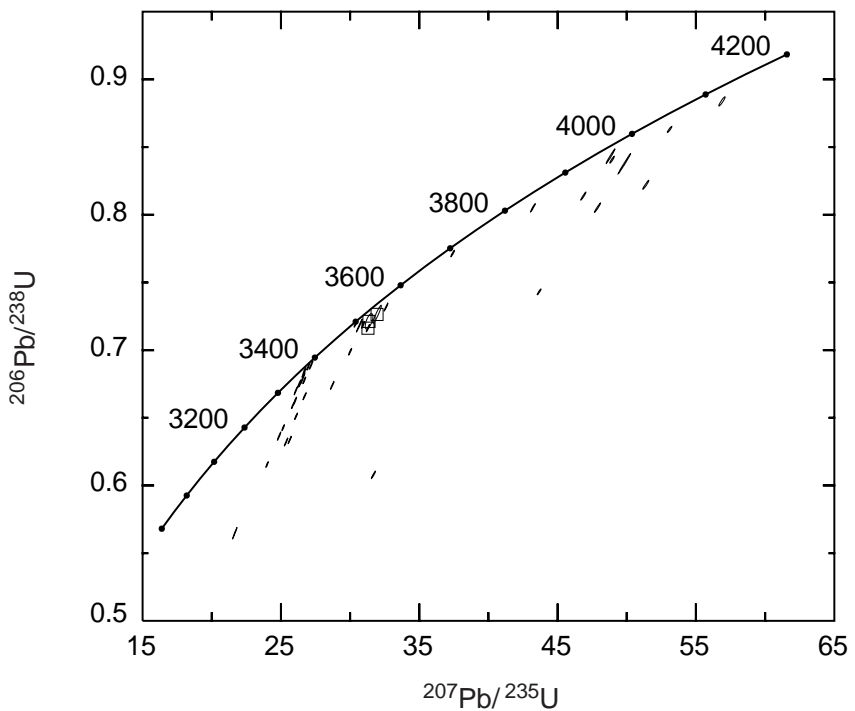

Figure $1 \mathrm{U}-\mathrm{Pb}$ concordia diagram for the single zircon grains and fragments analysed in this study. Error ellipses are $2 \sigma$. Three data points from Acasta gneiss zircons are marked with boxes. Numbers 3200-4200 are concordia age labels, millions of years.
Hf signature would be unradiogenic $\left(\epsilon_{\mathrm{Hf}}(T)<0\right)$.

At present, nearly all production of continental crust takes place by melting of mantle with a time-integrated history of depletion. This depletion is itself caused by extraction of crust from the mantle, so it provides an indirect monitor of the history of continental growth. Determining the record of mantle depletion is therefore of great importance. To compare recent crust-mantle differentiation with that of the early Earth we have investigated the Hf-isotope signatures of the oldest known detrital zircons from the Archaean Narryer Gneiss Complex in western Australia.

This complex includes two localities of sedimentary rocks containing unusually old zircons: the Mount Narryer quartzite ${ }^{10}$ and the Jack Hill metaconglomerate ${ }^{11}$. The latter is particularly significant because the fraction of zircon grains older than $4 \mathrm{Gyr}$ is relatively large: $12-20 \%$ (refs 1, 13), some being as old as $4.28 \mathrm{Gyr}$ (ref. 11). The trace-element concentrations and the mineralogy of inclusions in the Jack Hills detrital zircons, both 'old' and 'young', confirm the view that these zircons grew in felsic magmas ${ }^{12}$. Although the Jack Hills zircons have been dated by $\mathrm{U}-\mathrm{Pb}$ and analysed for traceelement concentrations ${ }^{12}$, no Lu-Hf-isotope determinations have been reported so far. An attempt to determine the Hf-isotope compositions of similar 4.20-3.75-Gyr Mount Narryer zircons using ion microprobe techniques ${ }^{19}$ yielded data of low precision $( \pm(5-7) \epsilon$ units at $2 \sigma)$, insufficient to resolve enriched or depleted crust and mantle components.

We have studied 37 single detrital zircon grains from the Jack Hills metaconglomerate for $\mathrm{Lu}-\mathrm{Hf}$ and $\mathrm{U}-\mathrm{Pb}$ (see table in Supplementary Information). The $\mathrm{U}-\mathrm{Pb}$ ages range up to $4.14 \mathrm{Gyr}$ (Fig. 1). Almost all of our $\mathrm{U}-\mathrm{Pb}$ analyses are less than $10 \%$ discordant (Fig. 1 and Supplementary Information) and about half are less than 3\% discordant. This is important because in a detrital single-grain study, where each grain is potentially unique, the reliability of $\epsilon_{\mathrm{Hf}}(T)$ cannot be checked by analyses of zircon fractions with varying $\mathrm{U}-\mathrm{Pb}$ discordance and by abrasion treatments, as has become standard practice in multigrain isotope studies ${ }^{4,15}$. The

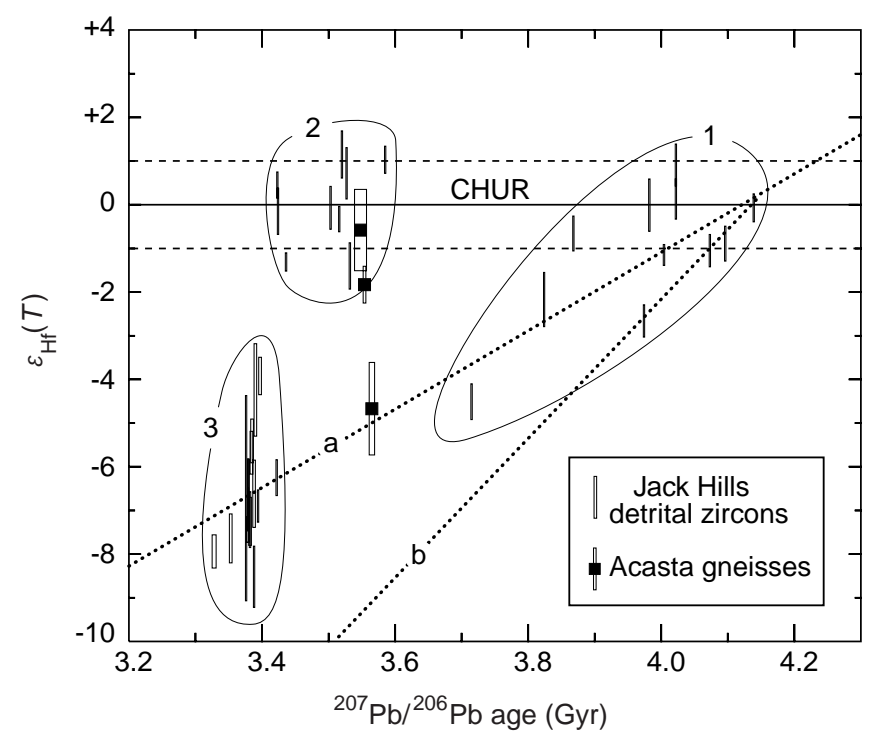

Figure $2 \mathrm{Hf}$-isotope evolution diagram for the Jack Hills and Acasta zircons. Error bars are $2 \sigma$. The Acasta data are marked with boxes. The chondritic reference line (CHUR) and its error limits (dashed lines) are from ref. 16. Groups of the Jack Hills data points (1,2 and 3 ) are discussed in the text. Dotted line a is the best-fit line through the Jack Hills data points of pre-3.7-Gyr and $\sim 3.38$-Gyr groups, corresponding to the evolution of mafic crust with ${ }^{176} \mathrm{Lu} /{ }^{127} \mathrm{Hf}=0.022$ (see text). Dotted line $b$ is the evolution trend of average granitoid crust with ${ }^{176} \mathrm{Lu} /{ }^{177} \mathrm{Hu}=0.0093$ (ref. 27). $\epsilon_{\mathrm{Hf}}(T)$ is a deviation, multiplied by $10^{4}$, of initial $\mathrm{Hf}$ isotopic ratio from the chondritic reference value (ref. 16). 
$\mathrm{Lu}-\mathrm{Hf}$ system in zircon is robust, and the only potential complication for initial ${ }^{176} \mathrm{Hf} /{ }^{177} \mathrm{Hf}$ determination would be the presence of domains with different ages and Hf-isotope compositions, for example, cores and overgrowths ${ }^{14,20}$. This problem is minimized by analysing zircons with little or no $\mathrm{U}-\mathrm{Pb}$ discordance $\mathrm{e}^{4,14,154,20}$.

Accurate determination of $\epsilon_{\mathrm{Hf}}(T)$ can be compromised by using a biased age value even for a zircon with uniform Hf-isotope composition, and this effect should also be evaluated. The effect of age on calculated $\epsilon_{\mathrm{Hf}}(T)$ is $2.2-2.5 \epsilon$ units per $100 \mathrm{Myr}$, due to the age dependence of the chondritic reference value. This problem may affect zircon that experienced ancient $\mathrm{Pb}$ loss. In such a case, the ${ }^{207} \mathrm{~Pb} /{ }^{206} \mathrm{~Pb}$ age is lower than the crystallization age, while the Hfisotope composition is not modified, so the apparent $\epsilon_{\mathrm{Hf}}(T)$ is shifted towards more negative values. Previous $\mathrm{U}-\mathrm{Pb}$ data ${ }^{11-13}$ have shown internal age heterogeneity in the Jack Hills zircon grains of the 'old' $(>3.8 \mathrm{Gyr})$ group. The possible bias in $\epsilon_{\mathrm{Hf}}(T)$ due to ancient $\mathrm{Pb}$ loss can be estimated from the difference between the 'whole grain' ${ }^{207} \mathrm{~Pb} /{ }^{206} \mathrm{~Pb}$ age reconstructed from fragment analyses, and the age of the oldest fragment taken as a proxy for crystallization age. Age biases between 'whole grains' and the oldest fragments for the five fragmented 3.8-4.1-Gyr Jack Hills zircons ${ }^{13}$ are between 8 and $61 \mathrm{Myr}$, corresponding to shifts in $\epsilon_{\mathrm{Hf}}(T)$ between 0.2 and $1.5 \epsilon$ units. The multiple spot ion microprobe analyses of 'old' Jack Hills zircons $^{11,12}$ indicate similar or smaller internal age variations, so a bias of $1.5 \epsilon$ units is a maximum estimate, and is likely to be much smaller for most grains.

The hafnium-isotope data are plotted as a function of age in Fig. 2. The data fall into three groups (Fig. 2): (1) 3.72-4.14-Gyr grains with $\epsilon_{\mathrm{Hf}}(T)$ between +0.9 and -4.5 ; (2) 3.42-3.58-Gyr grains with $\epsilon_{\mathrm{Hf}}(T)$ of +1.1 to -1.4 ; and (3) $\sim 3.38$-Gyr grains with $\epsilon_{\mathrm{Hf}}(T)$ between -3.9 and -8.5 . Five grains of the first group with ${ }^{207} \mathrm{~Pb} /{ }^{206} \mathrm{~Pb}$ ages $>4.0 \mathrm{Gyr}$ have nearly chondritic $\epsilon_{\mathrm{Hf}}(T)$, from +0.9 to -1.1 . The 3.7-4.0-Gyr grains have slightly lower $\epsilon_{\mathrm{Hf}}(T)$ values that correlate with age. The 3.38-Gyr group plots on the extension of this trend. Taken together, the 3.38-Gyr and pre-3.7Gyr grains form a scattered array in a plot of $\epsilon_{\mathrm{Hf}}(T)$ versus apparent age. The data for $\sim 3.6-G y r$ zircons plot as a compact group well above this array: their range of $\epsilon_{\mathrm{Hf}}(T)$ is relatively limited (2.5 $\epsilon$ units) and centres on the chondritic reference line.

Using these data, we can address two questions: the extent of depletion of the terrestrial mantle before $4 \mathrm{Gyr}$, and the nature of the earliest Archaean continental crust. It is clear that none of the 37 grains analysed appear to have come from a source that carried a significant record of depletion of the Earth's mantle. That is, no zircons have strongly positive $\epsilon_{\mathrm{Hf}}(T)$. The complete absence of depleted mantle signatures is in marked contrast with uniformly positive $\epsilon_{\mathrm{Hf}}(T)$ values in the Itsaq Gneiss Complex of west Greenland $^{4,21}$, the only early Archaean suite of rocks studied for Hf-isotope systematics.

The second notable feature of the data is the large proportion of zircons (more than half) that are derived from sources with timeintegrated enrichment (negative $\epsilon_{\mathrm{Hf}}(T)$ ). Clearly, much of the crust was already of a significant age when these zircons grew. The $\epsilon_{\mathrm{Hf}}(T)$ of magmas derived by episodic remelting of a particular crustal section would decrease with time because the ${ }^{176} \mathrm{Lu} /{ }^{177} \mathrm{Hf}$ ratio of the crust is lower than the chondritic value. It has been proposed that the earliest crust was mafic ${ }^{22,23}$. The ${ }^{176} \mathrm{Lu} /{ }^{177} \mathrm{Hf}$ ratios in crustal mafic rocks, including Archaean basalts and komatiites, are mostly between 0.015 and 0.028 (refs $24-26$ ), while ${ }^{176} \mathrm{Lu} /{ }^{177} \mathrm{Hf}$ ratios in Precambrian granitoids are lower still, between 0.001 and 0.023 , and averaging 0.0093 (based on the data from ref. 27). The $\epsilon_{\mathrm{Hf}}(T)$ versus time array of the 3.38-Gyr and pre-3.7-Gyr zircons (Fig. 2) can be interpreted to reflect the evolution of a crustal block, derived from the mantle at or before $4.14 \mathrm{Gyr}$. The slope of this array corresponds to ${ }^{176} \mathrm{Lu} /{ }^{177} \mathrm{Hf}=0.022$, consistent with the above range for crustal mafic rocks. It appears that very old $(>4.14-4.02-G y r)$ crust underwent a protracted history of remelting at 4.0-3.97, 3.8-3.7 and 3.38 Gyr. Complex internal age patterns of the 'old' zircon group ${ }^{11,13}$ indicate involvement of earlier granitoids in later melting episodes within this block. The 3.38-Gyr episode, which produced the most abundant fraction of the Jack Hills zircon population, was probably a major orogeny. The range of zircon ages indicates a duration of 20-30 Myr, and the range of initial Hf compositions of over $4.5 \epsilon$ units implies extensive mixing between pre-4.0 Gyr crust and younger crust.

The unradiogenic Hf-isotope compositions of some of the $\sim 4$ Gyr zircon grains allow evaluation of a minimum crustal residence time for the protoliths of parent rocks of the zircons. The $\epsilon_{\mathrm{Hf}}(T)$ value of -2.7 for the $3.97-\mathrm{Gyr}$ grain no. 40 requires a crustal residence time of $150 \mathrm{Myr}$ before the zircon crystallization, if a crustal block with average granitoid ${ }^{176} \mathrm{Lu} /{ }^{177} \mathrm{Hf}=0.0093$ (ref. 27) was derived from mantle with chondritic ${ }^{5} \mathrm{Lu}-\mathrm{Hf}$. This minimum estimate is essentially model-independent. Recently suggested alternative chondritic reference parameters ${ }^{28,29}$, or assumption of a depleted mantle source, or higher ${ }^{176} \mathrm{Lu} /{ }^{177} \mathrm{Hf}$ in the crustal block (more mafic crust) would all result in a larger value for the crustal residence time. Thus not only zircon grains but also crustal blocks, formed as early as $4.12-4.14 \mathrm{Gyr}$, were preserved for $150 \mathrm{Myr}$ or longer, rather than being recycled immediately to the mantle. Remnants of these crustal blocks, formed $\sim 100 \mathrm{Myr}$ before the oldest terrestrial crustal rocks known ${ }^{30,31}$, may still be found.

All data points of pre-4.0-Gyr zircons, as well as most of the $\sim 3.5-$ Gyr group, plot at or very close to the chondritic reference line (the range of $\epsilon_{\mathrm{Hf}}(T)$ from +1 to -1$)$. Although granitoids with $\epsilon_{\mathrm{Hf}}(T) \approx 0$ might be produced by mixing between older depleted mantle and enriched crust derivatives, such mixing would probably result in a broad range of initial isotope ratios from highly positive to strongly negative, contrasting with the consistent upper limit of $\epsilon_{\mathrm{Hf}}(T) \approx 0$ in the Jack Hills zircons. It is also possible that primary crust was derived from depleted mantle, but that crustal melting was fortuitously retarded for 200-300 Myr or more, allowing $\epsilon_{\mathrm{Hf}}(T)$ to evolve from positive to nearly zero values, but this ad hoc explanation is not predicted by comparisons with modern arcs. Therefore, we consider the most straightforward interpretation of the data as reflecting the derivation of primary crust from a mantle reservoir with nearly chondritic Hf-isotope composition, followed by early crustal differentiation. A chondritic Hf-isotope composition does not mean that the mantle was never melted. It could, for example, reflect an efficient large-scale mixing between depleted and enriched mantle. Our results are compatible with a chondritic mantle model and provide no indication that the bulk silicate earth has been fractionated in Lu/Hf by perovskite fractionation in a magma ocean $^{28}$, such that a chondritic reference model for the source of basalts might be inaccurate.

Our data set for 37 early Archaean detrital zircons indicates the need for further comparative studies. We have already analysed three 3.55-Gyr zircon grains from two samples of Acasta geneisses (northwest Canada; see Supplementary Information). The $\epsilon_{\mathrm{Hf}}(T)$ values are heterogeneous and vary from -0.6 to -4.7 , also indicating a long crustal pre-history, consistent with previous geochronological and $\mathrm{Nd}, \mathrm{Pb}$ isotope data ${ }^{6,730,31}$. The similarities in Hf-isotope composition between the Acasta gneisses and some of the source rocks of the Jack Hills conglomerate are consistent with previous suggestions of a relationship, based on $\mathrm{U}-\mathrm{Pb}$ data alone $\mathrm{e}^{13,30,31}$. Again, these preliminary data yield no indication of a depleted mantle component.

Depleted mantle and enriched mafic or felsic crust should have been produced as complementary reservoirs in the early Archaean, so finding isotopic signals from both enriched and depleted reservoirs can be expected. Current evidence for early Archaean depleted mantle, based upon Hf-isotope data from the Itsaq Gneiss Complex, has been presented by Vervoort et al. ${ }^{4}$ and by Vervoort and Blichert$\mathrm{Toft}^{21}$. However, the zircon populations of these polymetamorphic rocks are very complex, and obtaining the most reliable Hf-isotope 
data would require integrated $\mathrm{Lu}-\mathrm{Hf}$ and $\mathrm{U}-\mathrm{Pb}$ study of single grains or even fragments of grains. The conclusion of these authors ${ }^{21}$ that "there are no verified cases where any pre-3.5 Ga rocks have been derived from an older enriched reservoir" is inconsistent with our data which provide unequivocal evidence that such a reservoir did exist, and persisted for hundreds of Myr.

The results of our study raise questions concerning whether early Archaean depleted mantle was global or regional in extent, whether it formed and was rapidly remixed with less depleted components by convection, or whether it became inaccessible as a subsequent source of new crust. These are fundamental issues for future singlezircon $\mathrm{Lu}-\mathrm{Hf}$ research. Our data demonstrate that detrital zircon populations contain a wealth of information pertinent to these issues, which can be most reliably recovered using a combination of precise $\mathrm{U}-\mathrm{Pb}$ and $\mathrm{Lu}-\mathrm{Hf}$ isotope measurements. Some previous interpretations of the extent of early mantle depletion based on whole-rock studies, bulk zircon populations and less-precise analytical methods may need re-evaluation.

\section{Methods}

All zircons were hand-picked to avoid inclusions, fractures or turbidity, and airabraded $^{32}$. Some grains were broken into fragments ${ }^{13}$. Zircons were spiked with mixed ${ }^{235} \mathrm{U}-{ }^{205} \mathrm{~Pb}$ and digested in $\mathrm{HF}-\mathrm{HNO}_{3}$ in sealed bombs ${ }^{33}$ for $2-4 \mathrm{~d}$ at $20{ }^{\circ} \mathrm{C}$. Samples were dried and redissolved in $3.1 \mathrm{M} \mathrm{HCl}$. Separation of $\mathrm{U}$ and $\mathrm{Pb}$ was done on AG1x8 (200-400 mesh; Bio-Rad, Richmond, California) in $\mathrm{HCl}$ and $\mathrm{H}_{2} \mathrm{O}$ (refs 13, 33). Spiking with mixed ${ }^{176} \mathrm{Lu}-{ }^{180} \mathrm{Hf}$ (and sometimes ${ }^{149} \mathrm{Sm}-{ }^{150} \mathrm{Nd}$ ) was done at various stages: after $\mathrm{U}-\mathrm{Pb}$ chemical separation (grains 1-12), before digestion (grains 40-53 and zircons from Acasta gneiss), or on $95 \%$ aliquots in $3.1 \mathrm{M} \mathrm{HCl}$ before $\mathrm{U}-\mathrm{Pb}$ separation (grains 54-65). Experiments with two standard zircon samples (Y.A. et al., manuscript in preparation) have shown that all three spiking methods yield identical $\mathrm{Lu} / \mathrm{Hf}$ ratios. After spiking for $\mathrm{Lu}-\mathrm{Hf}$, all samples were returned to the $200^{\circ} \mathrm{C}$ oven with $1.0 \mathrm{M} \mathrm{HCl}-0.1 \mathrm{M} \mathrm{HF}$ to ensure sample-spike equilibration. Two-column separation of $\mathrm{Lu}$ and $\mathrm{Hf}$ follows the procedure described in ref. 15, except for the use of a smaller size of cation-exchange columns and the use of Ln-Spec resin (Eichrom, Dalrien, Illinois) instead of Teflon covered by HDEHP (bis-(2ethylhexyl) hydrogen phosphate) to separate $\mathrm{Hf}$ from $\mathrm{Zr}$. U, $\mathrm{Pb}$ and $\mathrm{Lu}$ were analysed at the Royal Ontario Museum by thermal ionization mass spectrometry (TIMS) using mostly an analogue Daly photomultiplier detector ${ }^{13,15}$. Hf was analysed by MC-ICPMS in static multicollector mode at the University of Michigan ${ }^{9,34}$. The JMC-475 standard was run between samples to monitor instrument performance and ensure negligible memory. Hf-isotope ratios of spiked samples were calculated from analyses by off-line numeric solution of isotope dilution equations with exponential normalization to ${ }^{179} \mathrm{Hf} /{ }^{177} \mathrm{Hf}=0.7325$. Procedure blanks of $0.2-0.5 \mathrm{pg} \mathrm{Lu}$ and $20-30 \mathrm{pg} \mathrm{Hf}$ were negligible for all samples.

\section{Received 24 August 1998; accepted 19 March 1999.}

1. Hamilton, P. J., O’Nions, R. K., Evensen, N. M., Bridgwater, D. \& Allaart, H. Sm-Nd isotopic investigations of Isua supracrustals and implications for mantle evolution. Nature 272, 41-43 (1978).

2. Jacobsen, S. B. \& Dymek, R. F. Nd and Sr isotope systematics of clastic metasediments from Isua, West Greenland: identification of pre-3.8 Ga differentiated crustal components. J. Geophys. Res. 93, 338354 (1988)

3. Bennett, V. C., Nutman, A. P. \& McCulloch, M. T. Nd isotopic evidence for transient, highly depleted mantle reservoirs in the early history of the Earth. Earth Planet. Sci. Lett. 119, 299-317 (1993).

4. Vervoort, J. D., Patchett, P. J., Gehrels, G. E. \& Nutman, A. P. Constraints on the early Earth differentiation from hafnium and neodymium isotopes. Nature 379, 624-627 (1996).

5. Moorbath, S., Whitehouse, M. J. \& Kamber, B. S. Extreme Nd-isotope heterogeneity in the early Archaean—fact or fiction? Case histories from northern Canada and West Greenland. Chem. Geol. 135, 213-231 (1997)

6. Browring, S. A., King, J. E., Housh, T. B., Isachsen, C. E. \& Podosek, F. A. Neodymium and lead isotope evidence for enriched early Archaean crust in North America. Nature 340, 222-225 (1989). Bowring, S. A. \& Housh, T. B. The Earth's early evolution. Science 269, 1535-1540 (1995).

8. Gruau, G., Rosing, M., Bridgwater, D. \& Gill, R. C. O. Resetting of Sm-Nd systematics during metamorphism of $>3.7$-Ga rocks: implications for isotopic models of early Earth differentiation. Chem. Geol. 133, 225-240 (1996).

9. Halliday, A. N. et al. Recent developments in inductively coupled plasma magnetic sector multiple collector mass spectrometry. Int. J. Mass Spec. Ion Proc. 146/147, 21-33 (1995).

10. Froude, D. O., Ireland, T. R., Kinny, P. D., Williams, I. S. \& Compston, W. Ion microprobe identification of 4,100-4,200 Myr-old terrestrial zircons. Nature 304, 616-618 (1983).

11. Compston, W. \& Pidgeon, R. T. Jack Hills, evidence of more very old detrital zircons in Western Australia. Nature 321, 766-769 (1986).

12. Maas, R., Kinny, P. D., Williams, I. S., Froude, D. O. \& Compston, W. The Earth's oldest known crust: A geochronological and geochemical study of 3900-4200 Ma old detrital zircons from Mt. Narryer and Jack Hills, Western Australia. Geochim. Cosmochim. Acta 56, 1281-1300 (1992).
13. Amelin, Y. V. Geochronology of the Jack Hills detrital zircons by precise U-Pb isotope dilution analysis of crystal fragments. Chem. Geol. 146, 25-38 (1998).

14. Patchett, P. J., Kouvo, O., Hedge, C. E. \& Tatsumoto, M. Evolution of continental crust and mantle heterogeneity: evidence from Hf isotopes. Contrib. Mineral. Petrol. 78, 279-297 (1981).

15. Corfu, F. \& Noble, S. R. Genesis of southern Abitibi greenstone belt, Superior Province, Canada: Evidence from zircon $\mathrm{Hf}$ isotope analyses using a single filament technique. Geochim. Cosmochim. Acta 56, 2081-2097 (1992)

16. Blichert-Toft, J. \& Albarède, F. The Lu-Hf isotope geochemistry of chondrites and the evolution of the crust-mantle system. Earth Planet. Sci. Lett. 148, 243-258 (1997).

17. Blichert-Toft, J., Chauvel, C. \& Albarède, F. Separation of Hf and Lu for high-precision isotope analysis of rock samples by magnetic sector-multiple collector ICP-MS. Contrib. Mineral. Petrol. 127, 248-260 (1997).

18. Stevenson, R. K. \& Patchett, P. J. Implications for the evolution of continental crust from Hf isotope systematics of Archean detrital zircons. Geochim. Cosmochim. Acta 54, 1683-1697 (1990).

19. Kinny, P. D., Compston, W. \& Williams, I. S. A reconnaissance ion-probe study of hafnium isotopes in zircons. Geochim. Cosmochim. Acta 55, 849-859 (1991).

20. Patchett, P. J. Importance of Lu-Hf isotopic system in studies of planetary chronology and chemical evolution. Geochim. Cosmochim. Acta 47, 81-91 (1983).

21. Vervoort, J. D. \& Blichert-Toft, J. Evolution of the depleted mantle: Hf isotope evidence from juvenile rocks through time. Geochim. Cosmochim. Acta (in the press).

22. Chase, C. G. \& Patchett, P. J. Stored mafic/ultramafic crust and early Archean mantle depletion. Earth Planet. Sci. Lett. 91, 66-72 (1988).

23. Galer, S. J. G. \& Goldstein, S. L. Early mantle differentiation and its thermal constraints. Geochim. Cosmochim. Acta 55, 227-239 (1991).

24. Taylor, S. R. \& McLennan, S. M. The Continental Crust, its Composition and Evolution (Blackwell Scientific, Oxford, 1985)

25. Condie, K. C. Chemical composition and evolution of the upper continental crust: contrasting results from surface samples and shales. Chem. Geol. 104, 1-37 (1993).

26. Rudnick, R. L. \& Fountain, D. M. Nature and composition of the continental crust: a lower crustal perspective. Rev. Geophys. 33, 267-309 (1995).

27. Vervoort, J. D. \& Patchett, P. J. Behaviour of hafnium and neodymium isotopes in the crust: constraints from Precambrian crustally derived granites. Geochim. Cosmochim. Acta 60, 3717-3733 (1996).

28. Salters, V. J. M. \& White, W. M. Hf isotopic constraints on mantle evolution. Chem. Geol. 145, $447-$ 460 (1998).

29. Vervoort, J. D., Patchett, J. P., Blichert-Tof, J. \& Albarède, F. Relationships between Lu-Hf and Sm-Nd isotopic systems in the global sedimentary system. Earth Planet. Sci. Lett. (in the press).

30. Stern, R. A. \& Bleeker, W. Age of the world's oldest rocks refined using Canada's SHRIMP: the Acasta Gneiss Complex, Northwest Territories, Canada. Geosci. Canada 25, 27-31 (1998).

31. Bowring, S. S. \& Williams, I. S. Priscoan $(4.00-4.03 \mathrm{Ga})$ orthogneisses from northwestern Canada. Contrib. Mineral. Petrol. 134, 3-16 (1999).

32. Krogh, T. E. Improved accuracy of U-Pb zircon ages using an air abrasion technique. Geochim. Cosmochim. Acta 46, 637-649 (1982).

33. Krogh, T. E. A low-contamination method for hydrothermal decomposition of zircon and extraction of $\mathrm{U}$ and $\mathrm{Pb}$ for isotope age determinations. Geochim. Cosmochim. Acta 37, 485-494 (1973).

44. Ballentine, C. J., Lee, D.-C. \& Halliday, A. N. Hafnium isotopic studies of the Cameroon line and new HIMU paradoxes. Chem. Geol. 139, 111-124 (1997).

Supplementary information is available on Nature's World-Wide Web site (http://www.nature.com) or as paper copy from the London editorial office of Nature.

Acknowledgements. We thank G. J. H. Oliver for providing the Acasta gneiss samples, and F. Corfu, D. Davis, U. Schaltegger, W. Mueller, F. Albarède and J. Patchett for comments on the manuscript. This work was supported by the NSERC, NSF and DOF.

Correspondence and requests for materials should be addressed to Y.A. (e-mail: yuria@rom.on.ca).

\section{A complete human pelvis from the Middle Pleistocene of Spain}

\section{Juan-Luis Arsuaga*, Carlos Lorenzo*, José-Miguel Carretero $\dagger$, Ana Gracia*, Ignacio Martínez*, Nuria García*, José-María Bermúdez de Castro $¥$ \& Eudald Carbonell\$}

* Departamento de Paleontología, Instituto de Geología Económica, Facultad de Ciencias Geológicas, Universidad Complutense de Madrid, 28040 Madrid, Spain $\dagger$ Departamento de Ciencias Históricas y Geografía, Facultad de Humanidades y Educación, Universidad de Burgos, 09071 Burgos, Spain

$\ddagger$ Museo Nacional de Ciencias Naturales, Consejo Superior de Investigaciones Cientificas, José Gutiérrez Abascal 2, 28006 Madrid, Spain

$\$$ Laboratori d'Arqueologia, Universitat Rovira i Virgili, Plaza Imperial Tarraco 1, 43005 Tarragona, Spain

The Middle Pleistocene site of Sima de los Huesos in Sierra de Atapuerca, Spain, has yielded around 2,500 fossils from at least 33 different hominid individuals ${ }^{1}$. These have been dated at more than 200,000 years ago ${ }^{2-4}$ and have been classified as ancestors of Neanderthals $^{5,6}$. An almost complete human male pelvis (labelled Pelvis 1) has been found, which we associate with two fragmentary femora. Pelvis 1 is robust and very broad with a very long superior pubic ramus, marked iliac flare, and a long femoral neck. This 